\title{
Resusitasi Pengendalian Kerusakan Di Unit Perawatan Intensif
}

\author{
Dhanu Pitra Arianto,* Nurita Dian Kestriani \\ Fellow Konsultan Intensive Care, Konsultan Intensive Care Departemen Anestesi dan Terapi \\ Intensif Fakultas Kedokteran Universitas Padjajaran, Bandung, Indonesia
}

\begin{abstract}
Abstrak
Resusitasi dengan pengendalian kerusakanmenggambarkan suatu pendekatan ke perawatan awal pada pasien dengan cedera berat. Tujuan pendekatan ini untuk menjaga pasien tetap stabil dengan menghindari intervensi dan kondisi yang berisiko kepada keadaan perburukan dengan mengendalikan trias kematian, yaitu hipotermia, koagulopati, dan asidosis. Merupakan hal yang penting bahwa konsep dan kepraktisan pendekatan ini dipahami oleh semua yang terlibat dalam manajemen awal pasien trauma. Pendekatan ini dimulai dengan pemberian produk darah sejak awal, penghentian perdarahan dan pengembalian volume darah yang bertujuan untuk mengembalikan stabilitas fisiologis dengan cepat. Resusitasi dengan pengendalian kerusakan memilikibeberapa tambahan pendekatan dari bidang farmakologis dan laboratorium untuk meningkatkan perawatan pasien yang mengalami perdarahan. Pendekatan ini termasuk trombelastografi sebagai ukuran rinci kaskade pembekuan, asam traneksamat sebagai antifibrinolitik.
\end{abstract}

Kata kunci : hipotermia, koagulopati, asidosis, perdarahan masif

\section{Damage Control Resuscitation in Intensive Care Unit}

\begin{abstract}
Damage control resuscitation (DCR) describes an approach to the early care of very seriously injured patients. The aim is to keep the patient alive whilst avoiding interventions and situations that risk worsening their situation by driving the lethal triad of hypothermia, coagulopathy and acidosis. It is critical that the concepts and practicalities of this approach are understood by all those involved in the early management of trauma patients. Damage control resuscitation forms part of an overall approach to patient care rather than a specific intervention and has evolved from damage control surgery. It is characterised by early blood product administration, haemorrhage arrest and restoration of blood volume aiming to rapidly restore physiologic stability. The infusion of large volumes of crystalloid is no longer appropriate, instead the aim is to replace lost blood and avoid dilution and coagulopathy. In specific situations, permissive hypotension may also be of benefit, particularly in patients with severe haemorrhage from an arterial source. Damage control resuscitation has been augmented by both pharmacologic and laboratory adjuncts to improve the care of the hemorrhaging patient. These include thrombelastography as a detailed measure of the clotting cascade, tranexamic acid as an antifibrinolytic.
\end{abstract}

Keywords: hypothermia, coagulopathy, acidosis, massive bleeding

*DPA: Penulis Koresponden; E-mail:dhanupitra@gmail.com

Makalah ini merupakan preprint dan belum selesai menjalani proses review dan editing

\section{Pendahuluan}

Perdarahan masif setelah cedera tetap menjadi penyebab utama kematian pada pasien trauma. Perdarahan yang tidak terkontrol dilaporkan bertanggung jawab atas $40 \%$ kematian akibat trauma. ${ }^{1}$ 
Respons patofisiologi awal terhadap cedera berat dicirikan oleh trias kematian, yaitu hipotermia, koagulopati, dan asidosis yang mematikan secara klasik. Situasi ini sering secara cepat menjadi fatal kecuali jika dikoreksi dengan tepat. Bahkan ketika pada tahap awal pasien bertahan, namun seringkali terjadi beberapa disfungsi organ dan kerusakan organ seperti cedera paru akut, disfungsi ginjal dan hati, dan kegagalan sirkulasi. Situasi seperti itu adalah penyebab kuat dari morbiditas akhir dan kematian pada pasien cedera multipel. ${ }^{2}$

Resusitasi dengan pengendalian kerusakan atau Damage Control Resuscitation (DCR) bertujuan untuk mengurangi efek buruk ini dengan meminimalkan beban akibat bedah sedini mungkin. Pasien dirawatdiIntensive Care Unit (ICU) untuk resusitasi berkelanjutan dan pengembalian keadaan fisiologis. Setelah kondisi fisiologis stabil, rekonstruksi anatomis dilakukan untuk mengembalikan fungsi jangka panjang. Jika perlu tindakan bedah diawal, hanya berfokus melakukan intervensi yang diperlukan untuk menyelamatkan nyawa dan fungsi ekstremitas kemudian menstabilkan fisiologi pasien, menunda rekonstruksi definitif sampai pemulihan terjadi. ${ }^{3,4}$

Pada beberapa literatur dijelaskan bahwa stress selain pembedahan juga dapat berkontribusi terhadap proses aktivasi imun yang tidak teratur, termasuk episode hipotensi, iskemik jaringan, hipoksia, serta komplikasi awal seperti infeksi. ${ }^{5}$

Resusitasi dengan pengendalian kerusakan merupakan evolusi berbasis bukti dari protokol resusitasi yang berbeda-beda, yang telah dikembangkan selama bertahun-tahun. Dengan demikian, dapat dilihat bahwa manajemen ini harus diterapkan secara holistik kepada pasien karena banyak manfaatnya. ${ }^{1,2,6}$

\section{Pembahasan}

Resusitasi dengan pengendalian kerusakan merupakan bagian dari pendekatan keseluruhan untuk perawatan pasien trauma (Gambar 1). Pendekatan ini harus dimulai pada kontak pertama dengan pasien di lingkungan pra-rumah sakit sampai perdarahan dihentikan dan fungsi fisiologi terkoreksi. Oleh karena itu, pengenalan pasien berisiko tinggi sangat penting. Intervensi secara dini untuk mencegah gangguan fisiologis jauh lebih efektif daripada mencoba untuk memperbaiki dampak kerusakan setelah gangguan fisiologis muncul. ${ }^{1}$

\begin{tabular}{|l|l|}
\hline \multicolumn{1}{|c|}{ Borderline patients } & \multicolumn{1}{|c|}{ Factors with poor outcome } \\
\hline ISS $>40$ & \\
ISS $>20$ with AIS thorax $>2$ & \\
Abdominal / pelvic injury with shock & $\begin{array}{l}\text { Hemodynamic instability } \\
\text { Coagulopathy } \\
\text { Bilateral lung contusion } \\
\text { Bilateral femoral fracture }\end{array}$ \\
$\begin{array}{l}\text { Severe head injury } \\
\text { Raised ICP or rise intra-operatively } \\
\text { Initial PAWP }>24 m m H g\end{array}$ & $\begin{array}{l}\text { Acidosis }(\mathrm{pH}<7.24) \\
\text { Rassive transfusion }(10 \mathrm{~m})\end{array}$ \\
Rise $>6 \mathrm{mmHg}$ on nailing & Expected Operative time $>6 \mathrm{~h}$ \\
& Raised inflammatory markers \\
\hline
\end{tabular}

Gambar 1 Menentukan batas dan faktor yang terkait pada pasien dengan hasil yang buruk pada pasien trauma - ISS injury severity score, AIS abbreviated injury scale, ICP intracranial pressure, PAWP pulmonary artery wedge pressure $^{7}$

\section{Indikasi Resusitasi Dengan Pengendalian Kerusakan}

Pendekatan DCR harus dipertimbangkan pada semua pasien dengan trauma,menempatkan mereka pada risiko perdarahan yang signifikan atau gangguan fisiologis (Gambar 2). Hal ini 
mencakup pasien yang mengalami atau dicurigai mengalami cedera abdomen atau toraks, trauma pelvis, amputasi yang signifikan, fraktur multipel tulang panjang, dan cedera kepala. ${ }^{5}$ Damage Control Resuscitation telah berevolusi dari awalnya yang merupakan operasi dengan pengendalian kerusakan atau Damage Control Surgery (DCS). Damage Control Surgery terdiri dari tiga langkah, yaitu operasi yang dipersingkat untuk mengendalikan perdarahan dan kontaminasi, resusitasi di ICU, dan rencana operasi ulang dengan operasi definitif. Strategi resusitasi DCS berfokus pada penanganan asidosis dan pencegahan hipotermia saja namun, penanganan langsung koagulopati tidak ditekankan dalam DCS. Koagulopati yang diamati pada pasien hemoragik dianggap sebagai hasil dari resusitasi, asidosis, dan hipotermia. Sebaliknya, DCR langsung menangani koagulopati yang diinduksi trauma segera setelah pasienmasuk atau dalam pengaturan pra-rumah sakit. ${ }^{3}$

\section{Komponen Kunci Resusitasi Dengan Pengendalian Kerusakan}

Resusitasi dengan pengendalian kerusakan dalam penanganan trauma mengoreksi lebih awal dan lebih agresif kejadian koagulopati dan penurunan fungsi metabolik dengan memprioritaskan kontrol perdarahan. Komponen utama dari DCR, seperti: ${ }^{1,8}$

- Hipotensi permisif dan restriksi pemberian cairan

- Resusitasi hemostatik

- Rewarming

- Koreksi asidosis

- Penghentian perdarahan dengan teknik bedah dan non-bedah

\section{Hipotensi Permisif dan Restriksi Pemberian Cairan kristaloid}

Resusitasi cairan pada pasien multipeltrauma dengan infus cepat cairan kristaloid dalam jumlah yang besar dalam upaya mengembalikan volume darah dan tekanan darah yang bersirkulasi secara cepat memiliki beberapa konsekuensi yang berpotensi merugikan pasien seperti edema paru akut. Tujuan hipotensi permisif adalah menjaga tekanan darah tetap rendah untuk menghindari perburukan kondisi perdarahan oleh gangguan koagulasi hidrostatik dengan tetap mempertahankan perfusi organ akhir yang memadai. ${ }^{2,9}$ Kaafarani

Dalam istilah praktis ini klinisi menargetkan tekanan darah sistolik dari $70-90 \mathrm{mmHg}$ atau Mean Arterial Pressure (MAP) $50 \mathrm{mmHg}$. Pendekatan ini mengurangi fluktuasi penurunan dan peningkatan tekanan darah sistolik yang dapat mengganggu koagulasi darah yang terbentuk di daerah cedera yang menyebabkan perdarahan lebih lanjut. ${ }^{9}$

\begin{tabular}{|c|c|c|}
\hline Anatomic Parameters & Physiologic Parameters & Lab Parameters \\
\hline $\begin{array}{l}\text { Estimated ISS }>36 \\
\text { Penetrating abdominal injuries } \\
\text { Penetrating chest injuries } \\
\text { Open pelvic fracture } \\
\text { Long bone \# with head injury } \\
\text { Long bone \# with lung contusion } \\
\text { Truncal haemorrhage \& } \\
\text { amputation }\end{array}$ & $\begin{array}{l}\text { Weak or absent radial pulse } \\
\text { Core body temperature }<35^{\prime} \mathrm{C} \\
\text { Systolic } \mathrm{BP}<100 \mathrm{mmHg} \\
\text { Heart rate }>100 \\
\text { PaO2/FiO } 2<250 \\
\text { Urinary output }<50 \mathrm{ml} / \text { hour }\end{array}$ & $\begin{array}{l}\text { Lactate }>2.5 \mathrm{mmol} / \mathrm{L} \\
\text { Platelet count }<90.000 / \mathrm{ml} \\
\text { Fibrinogen }>1 \mathrm{~g} / \mathrm{dl} \\
\mathrm{PT}>16 \text { secs } \\
\mathrm{INR}>1.5 \\
\mathrm{Hb}<11 \\
\mathrm{pH}<7.2 \\
\text { Base deficit }<6\end{array}$ \\
\hline
\end{tabular}

Gambar 2 Indikasi Resusitasi Dengan Pengendalian Kerusakan ${ }^{7}$

\section{Resusitasi Hemostatik dan Protokol Transfusi Masif}

Bukti terbaru menunjukkan bahwa transfusi yang tepat, dapat mengurangi penggunaan produk darah secara keseluruhan. Transfusi masif didefinisikan sebagai pasien yang membutuhkan lebih dari 10unit sel darah merah pada 24 jam pertama. ${ }^{8,10}$

Protokol resusitasi hemostasis bertujuan untuk memberikan komponen sel darah merah (PRC), fresh frozen plasma (FFP) dan trombosit di sekitar rasio 1:1:1. Hal ini dikenal sebagai 
transfusi yang seimbang, pemberian PRC diimbangi dengan pemberian faktor koagulasi. Tanpa ini, dilusi faktor koagulasi akan memperburuk keadaan, hal ini memiliki potensi mengakibatkan spiral koagulopati dan memperburuk kejadian perdarahan. ${ }^{1,8}$

Kemajuan dalam metode laboratorium pada pasien yang menderita gangguan mekanisme pembekuan sekarang dapat dinilai lebih cepat dan akurat. Thromboelastography (TEG) memberikan informasi gambaran secara holistik koagulasi melalui analisis fungsi trombosit, kekuatan pembekuan,dan fibrinolisis. Dengan hasil yang tersedia dalam waktu 20 menit, TEG dapat mengukur fungsi keseluruhan kaskade koagulasi termasuk trombosit, sehingga menyederhanakan diagnosis koagulopati dan memudahkan tatalaksana lebih lanjut. ${ }^{2,7}$

\section{Rewarming}

Rewarming dapat meningkatkan vasodilatasi perifer sehingga meningkatkan perfusi jaringan. Rewarming dapat dilakukan dengan cara sebagai berikut: ${ }^{11,12}$

1. Rewarming eksternal pasif; dicapai dengan selimut hangat atau meningkatkan suhu kamar.

2. Rewarming eksternal aktif; melalui penggunaan perangkat pemanasan udara dan pemanas lainnya.

3. Rewarming aktif internal inti; pemanasan cairan infus yang diberikan dan penggunaan oksigen yang dihangatkan.

\section{Koreksi Asidosis}

Tatalaksana utama untuk memperbaiki kondisi asidosis metabolik pada cedera berat untuk pemulihan perfusi organ adalah melalui penggantian volume, memungkinkan untuk menormalkan kembali keseimbangan asam-basa oleh mekanisme homeostatis. Hal ini sulit dicapai sampai perdarahan dapat dikendalikan. ${ }^{13,14}$

\section{Kontrol Perdarahan Sejak Awal}

Bukanlah hal yang mudah untuk mengembalikan keadaan fisiologi normal sampai perdarahan benar-benar dihentikan. Oleh karena itu, kecepatan yang dicapai oleh kontrol perdarahan sangat penting. Fokus protokol pada trauma beratadalah pengiriman pasien secara cepat ke fasilitas yang memungkinkan untuk tatalaksana lanjutan kelainan ini. ${ }^{11,12,15}$

Penggunaan asam traneksamat dalam penanganan trauma telah diterapkan melalui beberapa penelitian untuk mengurangi kematian yang terkait dengan perdarahan bila diberikan selama resusitasi. Asam traneksamat berfungsi dengan menghalangi tempat perdarahan dengan mengikat lisin pada plasminogen dan sehingga menghambat fibrinolisis, yang mengakibatkan penghambatan degradasi pembekuan. ${ }^{15,16}$

Penelitian The Clinical Randomisation of an Antifibrinolytic in Significant Haemorrhage 2(CRASH-2)Trial, menunjukkan bahwa penggunaan asam traneksamat dapat mengurangi angka kematian yang diakibatkan oleh komplikasi perdarahan. Asam traneksamat harus diberikan dalam waktu 3 jam paska traumasecara intravena sebanyak 1gr dilanjutkan 1gr tetesan infus dalam 8 jam. Oleh karena itu terapi ini merupakan bagian dari protokol resusitasi awal. ${ }^{14,17}$

\section{Kesimpulan}

Konsep resusitasi dengan pengendalian kerusakan harus diterapkan di seluruh rangkaian perawatan mulai dari perawatan pra-rumah sakit, kemudian evaluasi di instalasi gawat darurat, setelah itu ke ruang operasi untuk DCS, lalu ke ICU, dan akhirnya kembali ke ruang operasi untuk perbaikan definitif. 
Pemberian cairan kristaloid yang terbatas mencegah koagulopati dilusional, menghindari potensiasi dari respons inflamasi yang berat, dan mengurangi risiko cedera paru akut.

Rewarming aktif mencegah koagulopati hipotermia yang tidak dapat dikoreksi dengan faktor pembekuan saja. Meskipun resusitasi dengan pengendalian kerusakan dapat mengurangi kematian akibat perdarahan, tetapi perdarahan tetap menjadi penyebab utama kematian sejak awal pada populasi dengan trauma dan penelitian lebih lanjut masih tetap dibutuhkan.

\section{Daftar Pustaka}

1. Ball CG. Damage control resuscitation: history, theory and technique. Can J Surg. 2014;57(1):55-60.

2. Duchesne JC, McSwain NE Jr, Cotton BA, et al. Damage control resuscitation: the new face of damage control. J Trauma-Inj Infect Crit Care. 2010;69(4):976-90.

3. Rotondo MF, Schwab CW, McGonigal MD, et al. 'Damage control': an approach for improved survival in exsanguinating penetrating abdominal injury. J Trauma. 1993;35(3):375-82 (discussion 382-3).

4. Lasanianos NG, Kanakaris NK, Dimitriou R, et al. Second hit phenomenon: existing evidence of clinical implications. Injury. 2011;42(7):617-29.

5. Fox CJ, Bowman JN. Advances in resuscitation in the setting of vascular injury. Perspect Vasc Surg Endovasc Ther. 2011;23(2):112-6.

6. Giannoudis PV, Dinopoulos H, Chalidis B, et al. Surgical stress response. Injury. 2006;37(Suppl 5):S3-9.

7. Schmidt BM, Rezende-Neto JB, Andrade MV, et al. Permissive hypotension does not reduce regional organ perfusion compared to normotensive resuscitation: animal study with fluorescent microspheres. World J Emerg Surg. 2012;7(Suppl 1):S9.

8. Spahn DR, Ganter MT. Towards early individual goal-directed coagulation management in trauma patients. Br J Anaesth. 2010;105(2):103-5.

9. Kaafarani HM, Velmahos GC. Damage control resuscitation in trauma. Scand J Surg. 2014;103(2):81-8.

10. McDaniel LM, Etchill EW, Raval JS, et al. State of the art: massive transfusion. Transfus Med. 2014;24(3):138-44.

11. Kobbe P, Lichte P, Wellmann M, et al. Impact of hypothermia on the severely injured patient. Unfallchirurg. 2009;112(12):1055-61.

12. Hildebrand F, Probst $\mathrm{C}$, Frink $\mathrm{M}$, et al. Importance of hypothermia in multiple trauma patients. Unfallchirurg. 2009;112(11):959-64

13. Kim Y, Lee K, Kim J, et al. Application of damage control resuscitation strategies to patients with severe traumatic hemorrhage: review of plasma to packed red blood cell ratios at a single institution. $\mathrm{J}$ Korean Med Sci. 2014;29(7):1007-11.

14. Langan NR, et al. Changing patterns of in-hospital deaths following implementation of damage control resuscitation practices in US forward military treatment facilities. JAMA Surg. 2014;149(9):904-12.

15. Fox CJ, Bowman JN. Advances in resuscitation in the setting of vascular injury. Perspect Vasc Surg Endovasc Ther. 2011;23(2):112-6.

16. Davenport R. Pathogenesis of acute traumatic coagulopathy. Transfusion. 2013;53(Suppl 1):23S-7S.

17. Kobbe $\mathrm{P}$, Lichte $\mathrm{P}$, Wellmann $\mathrm{M}$, et al. Impact of hypothermia on the severely injured patient. Unfallchirurg. 2009;112(12):1055-61. 